\title{
Objets de cuisine : technologie fermée ou changement évolutif?
}

Pier Giorgio Solinas

\section{(2) OpenEdition \\ 12 Journals}

Édition électronique

URL : https://journals.openedition.org/tc/623

DOI : $10.4000 /$ tc. 623

ISSN : 1952-420X

Éditeur

Éditions de l'EHESS

\section{Édition imprimée}

Date de publication : 1 septembre 1994

ISSN : 0248-6016

\section{Référence électronique}

Pier Giorgio Solinas, "Objets de cuisine : technologie fermée ou changement évolutif ? », Techniques \& Culture [En ligne], 21 | 1994, mis en ligne le 30 décembre 2005, consulté le 29 septembre 2022. URL : http://journals.openedition.org/tc/623 ; DOI : https://doi.org/10.4000/tc.623

Ce document a été généré automatiquement le 29 septembre 2022.

Tous droits réservés 


\section{Objets de cuisine : technologie fermée ou changement évolutif ?}

Pier Giorgio Solinas 